\title{
Teknik Fermentasi sebagai Upaya Pemanfaatan Pering Kelapa untuk Pakan Ikan di Desa Margaasih Kecamatan Cicalengka Kabupaten Bandung
}

\section{Fermentation Techniques as Efforts to Utilize Coconut Pering Waste for Fish Feed in Margaasih Village; Cicalengka District, Bandung Regency}

\author{
Kiki Haetami ${ }^{1, a}$, Junianto ${ }^{1}$, Abun $^{2}$ \\ ${ }^{1}$ Fakultas Perikanan dan Ilmu Kelautan, Universitas Padjadjaran Bandung \\ ${ }^{2}$ Fakultas Peternakan, Universitas Padjadjaran Bandung \\ aemail: kiki.haetami@gmail.com
}

\begin{abstract}
Abstrak
Desa Margaasih terletak di Kecamatan Cicalengka, Kabupaten Bandung, Jawa Barat. Desa Margaasih sebagian besar didominasi oleh lahan pertanian dan perkebunan. Luas wilayah perkebunan Desa Margaasih yaitu 22,00 Ha dan luas tanah sawah yaitu 121,05 Ha., diantaranya terdapat potensi peternakan dan perikanan. Kegiatan pengabdian masyarakat bertujuan sosialisasi pemanfaatan limbah pasar dan pertanian yang selama ini belum diolah menjadi suatu produk yang memiliki nilai guna, melalui proses fermentasi menggunakan jasa mikroba yang berasal dari lingkungan untuk pakan ikan. Hal tersebut memiliki arti penting, karena pakan alternatif hasil biokonversi mikroba dapat mengatasi ketergantungan terhadap pakan komersial sebagai pakan tambahan. Masyarakat cukup responsif dan antusias selama kegiatan, dapat dilihat dari keaktifan dan pastisipatif selama proses PPM terintegrasi berlangsung. Bahan pering kelapa mudah diperoleh sebagai limbah pasar yang lokasinya berdekatan dengan desa. Respon positif didapatkan oleh anggota kelompok tani Sugih Mukti di Desa Margaasih dengan mencoba proses fermentasi alamiah dari bahan pering kelapa menggunakan ragi (Saccharomyces sp.) dan jamur oncom (Neurospora sp.). Pengolahan limbah pering kelapa dapat dijadikan sebagai pakan alternatif untuk mengurangi penggunaan pakan komersil.
\end{abstract}

Kata Kunci : Sosialisasi pakan alternatif, fermentasi, limbah pering kelapa, pakan ikan, Margaasih.

\begin{abstract}
Margaasih Village is located in Cicalengka District, Bandung Regency, West Java. Margaasih village is mostly dominated by agricultural land and plantations. The plantation area of Margaasih Village is $22.00 \mathrm{Ha}$ and the area of rice fields is $121.05 \mathrm{Ha}$, among these, there is the potential of livestock and fisheries. Community service activities aim at socializing the use of market and agricultural waste that has not been processed into a product that has a use value, through the fermentation process using microbial services derived from the environment for fish feed. This has an important meaning, because alternative feeds from microbial bioconversion can overcome the dependence on commercial feed as additional feed. The community was quite responsive and enthusiastic during the activity, it can be seen from the active and participatory activities during the integrated PPM process. Coconut pering material is easily obtained as a market waste that is located close to the village. Positive responses were obtained by members of the farmer group Sugih Mukti in Margaasih Village by trying the natural fermentation process of coconut pering ingredients using yeast (Saccharomyces sp.) and oncom mushrooms (Neurospora sp.). Coconut pering waste treatment can be used as an alternative feed to reduce the use of commercial feed.
\end{abstract}

Key words: Socialization of feed alternate, fermentation, coconut pairing waste, fish feed, Margaasih.

\section{Pendahuluan}

Desa Margaasih adalah salah satu yang terletak di daerah timur kabupaten Bandung, termasuk wilayah yang berdekatan dengan pusat kota Kecamatan Cicalengka. Potensi sektor pertanian terdiri dari tanaman padi sebanyak $121 \mathrm{Ha}$, ubi kayu $60 \mathrm{Ha}$, dan jagung sebanyak $20 \mathrm{Ha}$, dan tanaman lain seperti kelapa. Beberapa masyarakat Desa Margaasih 
memiliki kolam di pekarangan rumah baik sebagai sarana pemeliharaan ikan untuk konsumsi, walaupun terdesak oleh lahan pemukiman dan proyek perumahan (real estate).

Budidaya perikanan sebagai penyedia gizi masyarakat, potensial untuk berkembang lebih jauh, salah satunya ikan nila sebagai komoditi ikan konsumsi yang preferensinya meningkat dari tahun ke tahun (BPS, 2004). Namun hal tersebut perlu didukung oleh persediaan pakan yang memadai melalui pemanfaatan sumber daya alam sekitar. Penyuluhan dan pelatihan mengenai sumber pakan alternative dipandang perlu untuk dilaksanakan melalui pengenalan dan pengolahan berbagai sumber limbah pertanian yang berasal dari kearifan lokal untuk dijadikan pakan ikan di Desa Margaasih. Hal inilah yang mendasari kegiatan Pengabdian kepada Masyarakat (PPM) yang bertemakan fermentasi pakan sebagai pakan alternatif dan sebagai upaya pemanfaatan limbah pertanian ketika sumber daya tersebut berlimpah. Diperlukan upaya introduksi produksi pakan sendiri, dalam rangka mengatasi persoalan pakan ketika kekurangan atau tidak mencukupi kebutuhan untuk ikan budidaya.

Berdasarkan observasi dan wawancara, ada beberapa permasalahan terkait hambatan pengembangan perikanan selain kondisi pengairan yang kurang saat musim kemarau, yaitu mahalnya pakan komersial dan keterbatasan pengetahuan pembudidaya mengenai pemanfaatan limbah pertanian yang dapat diolah untuk bahan pakan alternatif dan penyusun formula pakan ikan. Semua permasalahan tersebut berdampak pada rendahnya produktifitas pembudidaya ikan tradisional, dilain pihak ada beberapa potensi sumber bahan baku yang dapat diusahakan untuk mendapatkannya, seperti limbah hasil panen dan limbah pasar salah satunya kulit ari (pering) atau limbah pemarutan daging buah kelapa. Kelapa adalah bahan pangan sumber lemak, karbohidrat dengan kandungan protein yang masih memadai untuk pakan ikan dibanding limbah hijauan palawija, namun sangat cepat rusak yang menyebabkan potensi bahan lokal tersebut belum dimanfaatkan secara optimal. Potensi limbah kelapa sebagai sumber energi untuk ikan dapat dikelola melalui fermentasi. Tim pengusul PPM bersama mitra menentukan bahwa permasalahan tersebut perlu ditangani, dengan tujuan dalam rangka pengawetan bahan limbah menjadi pakan. Hal ini terkait pula dengan himbauan Zero waste dalam upaya untuk perbaikan lingkungan.

Limbah kulit ari daging buah kelapa atau disebut pering kelapa, dapat rmenjadi sumber energi bagi ikan dengan memperhatikan proses pengolahannya. Teknologi fermentasi secara alami dari bahan limbah kulit ari kelapa dengan jamur oncom dan jamur tape, adalah salah satu upaya teknik pengolahan. Komoditas palawija dan kelapa (terutama limbah pering kelapa) masih dapat ditingkatkan pemanfaatannya semaksimal mungkin melalui teknologi fermentasi, dan dapat dijadikan sebagai bahan pakan alternatif dan suplemen dalam penyediaan pakan.

Tujuan dari kegiatan ini adalah sosialisasi pemanfaatan limbah pasar dan pertanian yang selama ini belum diolah menjadi suatu produk yang memiliki nilai guna, melalui proses fermentasi menggunakan jasa mikroba yang berasal dari lingkungan untuk pakan ikan. Kegunaan kegiatan ini adalah sebagai transfer ipteks yang kemudian dapat diaplikasikan dalam produksi pakan sendiri (on farm feed) dalam rangka menunjang usaha budidaya ikan dan membantu kelompok tani Sugih Mukti dalam memecahkan persoalan pakan.

\section{Materi dan Metode Pelaksanaan}

Prinsip fermentasi adalah pengolahan biologis menggunakan jasa mikroba, baik secara alamiah maupun melalui penambahan inokulum ragi/kapang Pengolahan limbah pering kelapa dilakukan sebagai berikut:

- Penyiapan inokulum ragi tape dan jamur oncom, baik berasal dari kultur murni dari laboratorium maupun menggunakan ragi tape dan oncom merah yang dibuat inokulum dengan menggiling laru oncom dengan campuran tepung.

- Limbah pering kelapa disterilisasi melalui pengukusan 10" kemudian didinginkan di dalam wadah.

- Ditaburkan bubuk inoculum, pada wadah pertama menggunakan ragi Saccharomyces $s p$. (ragi tape), wadah kedua diberikan inokulum Neurospora sp. (jamur oncom).

- Setelah inoculum dicampur rata dengan limbah pering kelapa, kemudian dimasukkan pada kantung-kantung plastik yang diberi label (Saccharomyces sp. dan Neurospora $s p$.), dan selanjutnya ditusuk- 
tusuk dengan jarum/peniti, untuk mempermudah fermentasi secara aerob.

- Proses fermentasi dilakukan pada rak fermentasi selama 3 hari untuk fermentasi oleh Saccharomyces sp. dengan dosis 2\% (Haetami, 2018) dan 5 hari untuk fermentasi oleh Neurospora $s p$. dengan dosis $1 \%$ (Pahlevi et al., 2008).

Jamur Neurospora sp akan menguraikan lemak dan serat kasar (Chandel et al. 2007), dan dapat tumbuh dengan kondisi aerobik pada suhu $20-30^{\circ} \mathrm{C}$ (Judoamidjojo et al. 1989), serta menurut Amer dan Stephen (1982) kelas Ascomycetes ini dapat mendegradasi lignin dan bahan lignoselulotik. Adapun menurut Leiskayanti et al. (2017), bioproses melalui fermentasi tidak membutuhkan sterilisasi, bisa diberikan tanpa mempertimbangkan jenis serta komposisi zat pengikat (binder), dilakukan secara nonekstrusi atau tanpa menggunakan mesin pembuat pakan apung (ekstruder), dan tanpa tahapan deep frying sehingga lebih hemat energi dan jauh lebih praktis.

Metode Pelaksanaan kegiatan dimulai dari tahapan sosialisai rencana kegiatan, saresehan dan perkenalan dengan ketua dan anggota Kelompok Tani Sugih Mukti, dan didampingi pula dengan pihak terkait yaitu petugas pertanian lapangan dari Dinas Perikanan, Pangan, dan Pertanian. Tahapan Introduksi pengolahan pering kelapa adalah dengan peragaan proses fermentasi skala kecil (volume $10 \mathrm{~kg}$ ) yang berlangsung secara aerob dan anaerob, untuk menunjukkan pertumbuhan jamur pada limbah pering kelapa dalam wadah kantung-kantung plastic yang disimpan dalam kardus/rak fermentasi. Proses berlangsung selama lima hari, hasilnya dipanen dan dicobakan ke ikan sebagai pakan tunggal. Pering kelapa hasil fermentasi sebagian diblender untuk memperhalus ukurannya untuk diberikan dalam campuran formulasi pakan ikan.

Dari analisis kesesuaian, lokasi Desa Margaasih berdekatan dengan pasar tradisional Cicalengka, sehingga limbah pering kelapa dengan mudah didapatkan. Selain itu dengan potensi tanaman kelapa dan palawija di perkebunan dan sekitar lokasi pesawahan/kolam, bahan baku pakan yang dapat diolah cukup berlimpah. Hal inilah yang perlu dimotivasi kepada kelompok tani untuk mencoba menggiatkan kembali budidaya ikan, melalui introduksi fermentasi pering kelapa.
Selain diperkenalkan pembuatan pakan alternatif dengan memanfaatkan limbah pering kelapa, juga memotivasi keberlanjutan usaha perikanan di kolam terpal yang telah dicoba oleh anggota kelompok tani Sugih Mukti.

Kegiatan inovasi teknologi pemanfaatan limbah pertanian dan limbah pasar menjadi pakan ikan, pelaksanaannya dalam beberapa tahapan, yaitu :

- Sosialisasi pembuatan pakan ikan dari limbah pering kelapa dengan teknik fermentasi pada anggota Kelompok Tani Sugih Mukti Desa Margaasih.

- Diskusi fermentasi pering kelapa dan limbah pertanian lainnya (silase hijauan).

- Pengolahan tahap akhir fermentasi pakan ikan dan percobaan pemberian pakan ikan hasil fermentasi.

- Evaluasi kegiatan melalui daftar pertanyaan ke sasaran pelatihan untuk memperoleh informasi lengkap yang dibutuhkan untuk mendukung kegiatan budidaya ikan.

\section{Hasil dan Pembahasan}

Hasil kunjungan ke kantor Desa Margaasih, dan sekretariat kelompok Tani Sugih Mukti Desa Margaasih, Kecamatan Cicalengka, didapatkan sambutan yang cukup ramah dan mendapat respon yang baik, antara lain dengan memberikan informasi mengenai sekilas profil Desa Margaasih. Hasil survey didapatkan bahwa lokasi mitra kegiatan PPM didominasi perkebunan (jagung, kelapa dan palawija lainnya) dan tidak jauh dengan kota kecamatan $( \pm 2 \mathrm{~km})$ sebagai akses pasar tradisional Cicalengka. Berdasarkan hal tersebut limbah pemarutan kelapa adalah bahan baku yang cocok sebagai pakan ikan alternatif, karena mudah ditepungkan dan diingkatkan kualitasnya melalui fermentasi.

Kegiatan PPM terintegrasi KKNM ini meliputi: (1) kegiatan persiapan (survey dan proposal); (2) kegiatan lapangan (keterlibatan, intensitas, kontribusi, kreativitas, dan inisiatif dalam kegiatan kelompok) (3) kegiatan pengabdian (jenis kegiatan, durasi kegiatan, modul/bahan kegiatan, ruang lingkup/target peserta) dan (4) evaluasi.

Kultur masyarakat Desa Margaasih dan potensi yang ada di desa tersebut adalah pertanian/perkebunan dan terdapat perikanan dengan adanya beberapa anggota kelompok tani yang berkegiatan budidaya baik kolam tanah maupun membuat kolam terpal. 
Ketersediaan limbah pertanian di sekitar desa Margaasih salah satunya limbah pering kelapa menjadi perhatian utama pada kegiatan KKNM terintegrasi PPM ini. Berdasarkan hasil wawancara dengan pembudidaya ikan, belum banyak diketahui informasi mengenai pemanfaatan limbah pertanian dan limbah pasar sebagai pakan alternatif. Salah satu pemilik kolam, yang juga berprofesi sebagai pedagang di pasar sedikitnya terdapat $10 \mathrm{~kg}$ limbah pering kelapa per harinya dapat diperoleh dari pemarutan kelapa. Terkait hal tersebut perlu introduksi pengolahan pakan alternatif melalui teknik fermentasi pakan dari limbah pasar (pering kelapa) yang cukup mudah tersedia untuk pakan ikan. Hal ini ditujukan untuk menghemat biaya pakan dalam upaya menumbuhkan gairah masyarakat dalam budidaya ikan untuk mencukupi kebutuhan gizi masyarakat.

Pengolahan pering kelapa melalui proses fermentasi dilakukan selama lima hari. Pada tahap akhir fermentasi (setelah dibiarkan selama 5 hari), terdapat perbedaan pertumbuhan jamur dari perlakuan proses fermentasi yang aerob dan anaerob, yaitu tumbuhnya jamur pada limbah pering kelapa fermentasi aerob. Maka dari itu, dapat dibuktikan bahwa Saccharomyces sp. dan Neurospora sp. dapat tumbuh pada lingkungan aerob. Pada hasil fermentasi yang terdapat jamur tumbuh (aerob), kantung plastic dibuka dan hasil fermentasi limbah pering kelapa tersebut kemudian dioven hingga kering. Setelah selesai dioven, kemudian hasil fermentasi tersebut diblender untuk memperhalus ukurannya. Selanjutnya hasil fermentasi tersebut dapat digunakan, baik sebagai pakan tunggal maupun sebagai bahan baku pembuatan pellet ikan.

Berdasarkan analisis laboratorium Kimia Makanan Ternak dan Nutrisi Ternak Ruminansia (2019), terjadi peningkatan kualitas limbah pering kelapa hasil fermentasi. Kandungan protein meningkat dari 5,75\% menjadi 11,32\% (produk Neurospora) dan 12\% (produk Saccharomyses). Sedangkan kandungan serat kasar menurun, dari 26,48\% menjadi $11,79 \%$ (produk Neurospora) dan 12,26\% (produk Saccharomyses). Hal tersebut menunjukkan bahwa produk fermentasi pering kelapa cukup memenuhi syarat untuk dijadikan pakan ikan nila, sebagai ikan omnivore.

Berdasarkan hasil evaluasi dari penyuluhan dan pelatihan dengan metode purposive sampling melalui wawancara yang telah dilakukan, umumnya peserta memiliki minat dalam pemanfaatan limbah organik sebagai pakan ikan. Bahan baku pakan haruslah mempunyai nilai gizi yang baik, mudah diperoleh, mudah diolah, tidak mengandung racun harga relatif murah, serta bukan merupakan makanan pokok manusia (Mujiman, 1991). Limbah kulit ari dari daging buah kelapa (pering kelapa) memiliki potensi besar untuk digunakan sebagai bahan pakan alternatif karena memiliki ketersediaan tinggi, tidak bersaing dengan manusia. Hal ini direspon pula oleh salah satu pembudidaya ikan yang memiliki mata pencaharian utama sebagai pedagang di pasar.

Tabel 1. Indikator dan Pencapaian Introduksi Teknik Fermentasi

\begin{tabular}{|c|c|c|c|}
\hline No. & Metode kegiatan & Indikator keberhasilan yang diukur & Pencapaian \\
\hline 1. & $\begin{array}{l}\text { Penyuluhan dan } \\
\text { pelatihan fermentasi } \\
\text { pering kelapa }\end{array}$ & $\begin{array}{l}\text { 1. Memanfaatkan limbah kelapa } \\
\text { yang sudah tidak terpakai } \\
\text { 2. Transfer pengetahuan bagi } \\
\text { pembudidaya } \\
\text { 3. Mengurangi pemberian pakan } \\
\text { komersil }\end{array}$ & $\begin{array}{l}\text { Pembudidaya mempraktekan } \\
\text { dan mencoba hasil } \\
\text { fermentasi baik sebagai } \\
\text { pakan tunggal maupun } \\
\text { pakan tambahan. }\end{array}$ \\
\hline 2. & $\begin{array}{l}\text { Pengenalan teknik } \\
\text { Fermentasi lain }\end{array}$ & $\begin{array}{l}\text { 1. Memanfaatkan hijauan untuk } \\
\text { pembuatan silase, } \\
\text { 2. Memanfaatkan limbah kotoran } \\
\text { sapi untuk budidaya cacing sutra } \\
\text { dan merangsang pembentukan } \\
\text { flock (bioflock). }\end{array}$ & $\begin{array}{l}\text { Pembudidaya mengenal } \\
\text { pembuatan silase dan } \\
\text { bioflok untuk stok pakan } \\
\text { ternak/ikan sebagai } \\
\text { fermentasi alamiah. }\end{array}$ \\
\hline
\end{tabular}


Pada awal konseling peserta kelompok tani sugih mukti yang memiliki minat untuk memanfaatkan limbah pering kelapa adalah sebesar $50 \%$ sedangkan setelah konseling peserta yang memiliki minat meningkat menjadi $70 \%$. Kelompok Tani Sugih Mukti berperan aktif dalam rangkaian kegiatan, menyediakan bahan limbah untuk dilakukan proses fermentasi dan menerapkan hasil introduksi fermentasi. Secara keseluruhan, pada akhir penyuluhan peserta (anggota kelompok tani) memiliki minat untuk memanfaatkan limbah organik sebagai pakan ikan. Kelompok Tani Sugih Mukti dan innovator, berperan aktif dalam rangkaian kegiatan, menerapkan hasil introduksi fermentasi, ikan merespon dengan baik, tingkat penerimaan (acceptabilitas) hasil fermentasi limbah pering kelapa tersebut sangat baik, sehingga dapat digunakan sebagai pakan tambahan dan menghemat penggunaan pakan kmersil sebesar $50 \%$ atau mengurangi penegeluaran sebesar $\mathrm{Rp} 6000$,- per kg pakan, Hal ini sesuai dengan pendapat Amri dan Khaeruman (2003), bahwa ikan nila sangat responsif terhadap pakan.

Rencana keberlanjutan program adalah perlu dilakukannya pemotivasian kepada para petani ikan untuk memanfaatkan lahan pekarangan dengan kolam karpet dan produksi pakan ikan sendiri (on farm feed), berbasis bahan pakan alternatif dari limbah pering kelapa hasil fermentasi.

\section{Kesimpulan}

Masyarakat cukup responsif dan antusias selama kegiatan, dapat dilihat dari keaktifan dan pastisipatif selama proses PPM terintegrasi berlangsung. Bahan pering kelapa mudah diperoleh sebagai limbah pasar yang lokasinya berdekatan dengan desa. Respon positif diperlihatkan oleh anggota kelompok tani Sugih Mukti di Desa Margaasih salah satunya dengan mencoba proses fermentasi alamiah pengolahan pering kelapa, menggunakan ragi (Saccharomyces sp.) dan jamur oncom (Neurospora sp.) dan menerapkan nya sebagai pakan ikan dalam menunjang budidaya. Pengolahan limbah pering- kelapa dapat dijadikan sebagai pakan alternatif untuk mengurangi penggunaan pakan komersil.

\section{Ucapan Terimakasih}

Terimakasih penulis sampaikan kepada DRPM Unpad atas Dana PPM-Internal Unpad dan dukungan terselanggaranya kegitan KKNM-PPM Integratif Batch 1 tahun 2019.

\section{Daftar Pustaka}

Amer, G. I. dan Stephen W.D. 1982. Microbiology of Lignin Degradation. In D.Perlman (ed.). Annual Report on Fermentation Processes. New York: Vol 4. Academic Press.

Amri, K. dan Khairuman. 2003 Budidaya Ikan Nila secara Intensif. Agromedia Pustaka, Jakarta. $145 \mathrm{hlm}$.

BPS 2004. Statistik Perikanan Budidaya Indonesia. Departemen Kelautan dan Perikanan. Dirjen Perikanan Budidaya. Jakarta.

Chandel, A.K., Chan., Rudravaram, Narasu, L.V., Rao, dan Ravindra. 2007.

Economics and Environmental impact of Bioetanol Production Technologies; An Appraisal Biotechnology and Molecular Biology Review. Vol. 2 (1): 14-32.

Data Potensi Desa Margaasih, 2019. Kecamatan Cicalengka, Kabupaten Bandung.

Haetami, K. Abun, Y. Mulyani. 2018. Prebiotics $^{B A S}$ (Bacillus sp., Aspergillus $n$., and Sacharomyces c.) as Feed Supplement on Nutrients and its Effects on Digestibility Value of Fish Feed. International Journal of Environment, Agriculture and Biotechnology (IJEAB) 3(5)34.

Judoamidjojo, R.M., E.G. Said dan L. Hartoto. 1989. Biokonversi. Departemen Pendidikan dan Kebudayaan, Direktorat Pendidikan Tinggi. Pusat Antar Universitas Bioteknologi, Institut Pertanian Bogor. Bogor.

Leiskayanti Y, Sriherwanto C, Suja'i I (2017) Fermentasi menggunakan ragi tempe sebagai cara biologis pengapungan pakan ikan. $J$ Bioteknol Biosains Indonesia 4:54-63.

Mujiman, A. 1991. Makanan Ikan. Penebar Swadaya Jakarta.

Pahlevi, Y.W., Estiasih, T., Saparianti, E. 2008. Mikroenkapsulasi Ekstrak Karoten dari Spora Kapang Oncom Merah (Neurospora Sp.) dengan Bahan Penyalut Berbasis Protein 
Haetami / Media Kontak Tani Ternak, Februari 2020, 2(1):12-17

Menggunakan Metode Pengeringan

Semprot. Jurnal Fakultas Teknologi
Pertanian, Universitas Brawijaya, Malang. 